UDK 783.013 Agamben

DOI: $10.4312 / \mathrm{mz} .50 .2 .17-30$

\title{
Janet Danielson
}

Simon Fraser University, Canada

Univerza Simona Fraserja, Kanada

\section{Harmony, Sacrifice, and Agamben's Messianic Time}

\section{Harmonija, žrtvovanje in Agambenov mesijanski čas}

Prejeto: 2. januar 2013

Sprejeto: 27. marec 2013

Ključne besede: harmonija, sakralno, mesijanski čas, Giorgio Agamben, skladnja

\section{IZVLEČEK}

V dvajsetem stoletju so harmonija, svetost in celo čas veljali za ovire pri umetniškem ustvarjanju. Nasprotno so v starodavnih kulturah harmonijo pojmovali kot silo, ki povezuje vesolje. Giorgio Agamben je v novejših spisih o svetem in mesijanskem času drugače osvetlil pojav večglasja. Opozarja, da kapitalizem - polaščajoč se moči svetega - umetnost omejuje bodisi na spektakel, ali pa v predmet porabništva.
Received: 2nd January 2013

Accepted: 27th March 2013

Keywords: harmony, sacred, messianic time, Giorgio Agamben, syntax

\section{ABSTRACT}

In the early twentieth century, harmony, the sacred, and even time were seen as impediments to artistic freedom, though for the ancients, harmony was the integrating force of the cosmos. Giorgio Agamben's recent writings on the sacred and on messianic time shed new light on the emergence of polyphony. He warns that capitalism, subsuming sacral power, reduces art either to spectacle or to object for consumption.

Harmony, sacrifice, and time seem a discordant trio. Sacrifice is generally held to be an archaic custom rooted in superstition and violence. Harmony, in contrast, is an ideal state of peaceful co-operation. Time, at least in Newtonian physics, is neutral and impassive, flowing along equably without regard to anything external. ${ }^{1}$ But harmony,

1 Isaac Newton, "Scholium to the Definitions", in Philosophiae Naturalis Principia Mathematica, bk. 1 (1689); trans. Andrew Motte (1729), rev. Florian Cajori (Berkeley: University of California Press, 1934), 6. 
sacrifice and time have come together in striking intensity at crucial points in human history. In this paper I shall briefly review the radical shift in meaning of these three ideas at the beginning of the twentieth century, then look at some originary accounts involving harmony, sacrifice, and time; observe how they played out thirteenth-century polyphony; and finally explore their current significance, drawing on concepts from Giorgio Agamben's works.

In the years 1912-1913, three revolutionary European works provoked unprecedented audience outrage. The October 1912 première of Arnold Schoenberg's Pierrot Lunaire took place in Berlin. Its macabre centerpiece, the "Rote Messe," caricatured the Catholic liturgy, and Schoenberg's music dispensed altogether with harmony and melody. In May of the following year, the Paris première of Igor Stravinsky's Le Sacre du Printemps portrayed ritual sacrifice, its pounding rhythms impelling the victim's dance of death while its shrieking horns masked her cries. In St. Petersburg, December 1913, the futurist opera Victory over the Sun, some of it in an untranslatable language, celebrated the end of the past altogether: "How extraordinary life without the past is / Dangerous but without penitence and memories!" 2 Through the contrivance of art an "advanced" humanity dared to wrest mortality, harmony, and sacrificial ritual from the precinct of the gods: "All's well that begins well / And has no end / the world will perish but there's no end to us!"3 Chronos, Armonia, and Moloch were rendered mere spectacles; immortality belonged to the artist.

What prompted this spate of extravagant artistic production decrying harmony, sacrifice, and the past? Publications of the previous twenty years included Robertson Smith's influential Lectures on the Religion of the Semites (1894), which proposed taboo as the original sense of "sacred," and categorized it among the magical beliefs of "primitive society."

Rules of holiness in the sense just explained, i.e. a system of restrictions on man's arbitrary use of natural things, enforced by the dread of supernatural penalties, are found among all primitive peoples. It is convenient to have a distinct name for this primitive institution, to mark it off from the later developments of the idea of holiness in advanced religions, and for this purpose the Polynesian term taboo has been selected. ${ }^{4}$

Smith thus transmuted rites such as those of Stravinsky's Le Sacre into curiosities which the art and science of European "civilization" could safely explore. 5 Similarly, Schoenberg's devotees shrugged off charges of blasphemy in Pierrot Lunaire; what they had witnessed were simply the neurotic fantasies of the unconscious mind described in Sigmund Freud's 1899 The Interpretation of Dreams. And who could resist the thought of life without penitence? The creators of Victory over the Sun, influenced by Bergson's 
Creative Evolution (1907) and Ouspensky's ideas of the fourth dimension, thought that since three-dimensional space was a "vanquished phantom," time itself would be next to go. The ritual of becoming "mode"-ern entailed a renunciation of the "out-moded", for example in Paul Hindemith's conflicted introduction his 1943 harmony text:

Our old friend Harmony [...] has had to step down from the pedestal upon which general respect had placed her. In the [present] situation, in which faith in the magic power of the old rules of harmony is fast disappearing, and the future one, in which such rules will have interest only for the backward-glancing and analytical student, hardly anyone will feel a great desire to spend more time in the acquisition of harmonic knowledge than is absolutely necessary. ${ }^{7}$

Magic powers, old rules, the vanishing past-sacrificial practices, harmony, and time were thus recast as mere impediments to human freedom.

Sacrifice is the performance of sacred rites or the making of offerings for sacred use, often, but not exclusively, to secure divine favour. In the heady early years of the twentieth century, colonialism, industry, and science seemed a much surer way to secure the "preservation of favoured races." However, the year following our three premières ushered in not the promised era of freedom and prosperity, but rather World War I. The ensuing economic and social collapse of Europe, prompted Walter Benjamin to suggest that "it might be worthwhile to track down the origin of the dogma of the sacredness of human life." ${ }^{8}$ In response to Benjamin's challenge, Italian philosopher Giorgio Agamben has more recently re-opened the question of the sacred through his characteristic melding of philological and political investigation. In ancient Roman law, Agamben found, sacer can mean either exalted or banned, depending upon the gods to which the sacer person or object was consecrated: ${ }^{9}$

Sacred or religious were the things that in some way belonged to the gods. As such, they were removed from the free use and commerce of men [...] if 'to consecrate' (sacrare) was the term that indicated the removal of things from the sphere of human law, 'to profane' meant, conversely, to return them to the free use of men. ${ }^{10}$

The originary Greek and Hebrew accounts of the sacred are less abstractly legal than Roman legal accounts, and they invariably feature music. The Homeric Hymn to

6 Cf. Peter Stupples, "Malevich and the Liberation of Art", New Zealand Slavonic Journal (2001): 17, http://www.jstor.org/ stable/40922063. Accessed October 19, 2013.

7 Paul Hindemith, A Concentrated Course in Traditional Harmony Book 1 (New York: Schott, 1943), iii.

8 Walter Benjamin, "Critique of Violence" (1921), in Reflections: Essays, Aphorisms, Autobiographical Writings, ed. Peter Demetz; trans. Edmund Jephcott (New York: Schocken Books, 1978), 251.

9 Cf. Giorgio Agamben, Homo Sacer: Sovereign Power and Bare Life, trans. Daniel Heller-Roazen (Stanford, CA: Stanford University Press, 1998).

10 Giorgio Agamben, Profanations, trans. Jeff Fort (Cambridge, MA: Zone Books, 2007), 73. 
Hermes $^{11}$ combines our three themes of harmony, ${ }^{12}$ sacrifice, ${ }^{13}$ and time. The precocious baby Hermes is fascinated by the beauty of the shell of a large tortoise, and believing the tortoise shell to be more valuable as a resonator than as a house for a live animal, scrapes it out ${ }^{14}$ to create the first lyre with seven concordantly-tuned strings-the first use of concord in the Greek language, according to the translator. ${ }^{15}$ He then steals fifty of Apollo's cattle and invents fire so that he can sacrifice two of them before returning to his cradle to escape his brother's ire. As a god, Hermes can flagrantly transgress the laws of time; but the musical concord he established became normative in Greek thought. The early Pythagoreans took harmony to be the pattern and the integrating rule of the cosmos. Philolaus wrote:

Nature in the universe was harmonized from unlimiteds and limiters, both the whole universe and all things in it [...] for such [unlike] things it was necessary to have been locked together by harmonia, if they were to be held together in a cosmos. ${ }^{16}$

Plato concurred: "Concordant sounds provide pleasure and delight because of the imitation of the divine harmonia that comes into being in mortal movements." ${ }^{17}$ Later Greek writers such as Theon of Smyrna ( $2^{\text {nd }}$ cent. CE) still saw the Hermes story as key to understanding the sacred: "The seven-stringed lyre of Hermes is the image of the divine world." 18

In ancient Israel, Levites were appointed for priestly duties consisting mainly of sacrificial rites in which choral and instrumental music was an integral part. A signal from the priests' silver trumpets marked or even effected the transition from profane to sacred (Numbers 10:10, 2 Chron. 5:12-14, 29:25-28). Other ancient writings attest to music's pivotal role in sacrifice; in the words of third-century Chinese sage Juan Chi, "When music is played at the round hill [heaven] heavenly spirits will descend; when it is played at the square mound [earth], earthly spirits will arise. When heaven and earth thus unite their virtues, all beings will be concordant in their lives." ${ }^{19}$ Music is thus both signal and symbol of consecration; through participation in cyclic sacrificial rituals, humans become attuned to the immaterial, diffuse, and concordant presence of the divine.

11 Andrew Barker, Greek Musical Writings I: The Musician and his Art (Cambridge: Cambridge University Press, 1984), 43.

12 John Curtis Franklin, "Diatonic Music in Greece: A Reassessment of Its Antiquity," Memnosyne, Fourth Series, Vol. 55, Fasc. 6 (2002): 676, http://www.jstor.org/stable/4433380. Accessed June 19, 2013.

13 Richard. W. Johnston and David Mulroy, "The Hymn to Hermes and the Athenian Altar of the Twelve Gods", The Classical World, vol. 103, no. 1 (Fall 2009): 11, http://www.jstor.org/stable/40599900. Accessed June 19, 2013.

14 Barker, Greek Musical Writings I, 43: "He scooped the life out of the mountain tortoise" (italics mine). Agamben's Home Sacer, Agamben opens with an explanation of the difference between two Greek words for life: zoe, or 'bare life', and bios, or life in the community. But interestingly, the Greek word for the tortoise's life in this account is neither zoe nor bios, but aeon, a word often translated "time."

15 Franklin, "Diatonic Music in Greece: ...", 676.

16 Philolaus, frag. 1, 6 in Arthur Barker, Greek Musical Writings II: Harmonic and Acoustic Theory (Cambridge: Cambridge University Press, 1989), 36-37.

17 Plato, Timaeus 79e-80b, in Barker, Greek Musical Writings II, 63.

18 Theon of Smyrna, "The Order of the Planets and the Celestial Concert", book II, chapter 15, in Joscelyn Godwin, ed., The Harmony of the Spheres: A Sourcebook of the Pythagorean Tradition in Music (Rochester, Vermont: Inner Traditions, 1993), 19.

19 Kenneth J. DeWoskin, A Song for One or Two: Music and the Concept of Art in Early China (Michigan Monographs in Chinese Studies Volume 42. Ann Arbor, MI: Centre for Chinese Studies, The University of Michigan, 1982), 87. 
The advent of Christianity was closely followed by the destruction of the Temple and the end of the Jewish practice of temple sacrifice. The clear mortality/immortality boundary between the profane and the sacred had been breached. Agamben claims that "in Christianity, with the entrance of God as the victim of sacrifice [...] the divine sphere is always in the process of collapsing into the human sphere and man always already passes over into the divine." ${ }^{20}$

Agamben's study of the Book of Romans, The Time That Remains, deals in depth with the permeability of the temporal boundary. On Agamben's account, the Apostle Paul sees time so differently that none of the poetic forms he knows will suffice to carry its meaning. Pauline secular time or chronos spans from creation to the messianic event, Jesus' resurrection. Here time contracts itself and begins to end. This contracted time, which Paul calls ho nyn kairos, "the time of the now," is the penultimate time, which lasts until the parousia, the full presence of the Messiah. ${ }^{21}$ Messianic time is "the time we need to make time end," a collapsing of the spatial metaphor for time so "the past is dislocated into the present and the present is extended into the past." ${ }^{22}$ This pleroma, or fullness of time, is characterized by recapitulation-the past becoming part of the "now time"-and by an intense focus on the penultimate. Agamben sees the immediate impact of Messianic time in the poetic writings of Paul, who brought the endings of each line into consonance, making the first known instances of end rhyme. ${ }^{23}$

\begin{tabular}{|l|l|}
\hline kai oi klaiontes & those weeping \\
hõs me klaiontes & as not weeping, \\
kai oi chairontes & those rejoicing \\
hõs me chairontes & as not rejoicing, \\
kai oi agorazontes & those buying \\
hõs me katachontes & as not possessing, \\
kai oi chromenoi ton kosmon & those using the world \\
hõs me katechromenoi & as not using it up (I Corinthians 7:29-31, \\
& Agamben's translation $\left.{ }^{24}\right)$ \\
\hline
\end{tabular}

Agamben's reading of kairos calls into question the commonplace of Western "linear time," upon which so much historiography rests - for example, A. C. Crombie's assertion that Christian time is a linear dimension "along which the world and mankind could fulfill an unique historical purpose." ${ }^{25}$ But Agamben's finding in kairos a possible origin for end-rhyme, suggests that something other than "historical purpose" contributed powerfully to the appearance of what is commonly known as "Western culture." The next part of this paper will document other repercussions of kairos consciousness in

20 Giorgio Agamben, Profanations, trans. Jeff Fort (Cambridge, MA: Zone Books, distributed by MIT Press, 2007$), 79$.

21 Giorgio Agamben, The Time That Remains: A Commentary on the Letter to the Romans, trans. Patricia Dailey (Stanford, CA: Stanford University Press, 2005), 63.

22 Ibid., 68,74 .

23 cf. W. Beare, "The Origin of Rhythmic Latin Verse", Hermathena, no. 87 (May 1956): 3-20, http://www.jstor.org/stable/23039054. Accessed May 26, 2013.

24 Agamben, The Time That Remains ..., 86.

25 A. C. Crombie, Science, Art and Nature in Medieval and Modern Thought (London: Hambleton Press, 1996), 368. 
early European culture, especially music.

References to kairos in Christian cultic practice are not hard to find, for Christian liturgy is explicitly an entry into kairos. The words "It is time (kairos) for the Lord to act," signal the start of the liturgy of St. John Chrystostom, still celebrated weekly. Elements of the liturgy such as the singing of the Psalms are seen as enactments of kairos: in his Letter to Marcellinus (ca. 350 CE) St. Athanasius commends the Psalms as a recapitulation of the entire Old Testament and a prophecy of the life, death, and ascension of Christ. He further suggests that the Psalms become present to the singer, or rather that the singer becomes present to God through singing the Psalms:

The marvel with the Psalter is that [...] the reader takes all its words upon his lips as though they were his own, and each one sings the Psalms as though they had been written for his special benefit, and takes them and recites them, not as though someone else were speaking or another person's feelings being described, but as himself speaking himself, offering the words to God as his own heart's utterance, just as though he himself had made them up. ${ }^{26}$

For Athanasius, the ancient words of the Psalms take on an immediacy, a spontaneity, and a fused speaker/author identity indicative of messianic time.

In his Confessions, St. Augustine famously grapples with the mystery of time: "Time can only be a kind of extension; but I do not know what it is an extension of." 27 Sound, of course, is purely temporal, but Augustine argues that it is impossible to measure it: what is in the past no longer exists, the present is without duration, and the future does not exist yet. "Therefore, what we measure is neither the future nor the past nor the present nor what is passing. Yet nevertheless we do measure time." In a sudden insight Augustine remembers his mentor's hymn "Deus creator omnium . .." 28 The rhythm of the Ambrosian hymn, Augustine realizes, demonstrates that time is more intention than extension. In anticipating the whole hymn, attending to its meaning while singing, and allowing the words to be retained in the memory, Augustine is brought back to kairos and the words of St. Paul:

Through Him I may apprehend in Whom I have been apprehended and that I may be gathered up from my former ways to follow the One, forgetting what is behind [Philippians 3:2-6] not wasted or scattered on things which are to come and things which will pass away, but intent and stretching forth to those things which are before-no longer distracted, but concentrated as I follow on for the prize of my heavenly calling, where I may hear the voice of Thy praise, and contemplate Thy delight which is neither coming nor passing. ${ }^{29}$

26 Athanasius, On the Incarnation: The Treatise De Incarnatione Verbi Dei (Crestwood, NY: St. Vladimir's Press, 1993 ), 105.

27 Augustine, Confessions Book XI Ch. 26, trans. Rex Warner (New York: New American Library, 1963 ), 279.

28 Augustine, Confessions Book XI Ch. 27, trans. Warner, 280.

29 Augustine, Confessions Book XI Ch. 29, trans. Warner, 283. 
The ideal of ceaseless praise prompted the rise of monastic living in Asia, Africa, and Europe. St. Brigit of Ireland claimed that angelic assistance enabled her to transcend both time and space: "I daily listen to the strains and spiritual melodies of the heavenly instruments [...] I can hear the masses of holy men which they celebrate to the Lord in distant lands as if they were close by. ${ }^{30}$ The entire book of Psalms was sung weekly in the seven daily monastic offices. Novices as young as ten years of age were required to memorize the Psalms in Latin in the process of becoming literate. ${ }^{31}$ The scarcity of books made memorization imperative, and end-rhyme was a great aid to memorization. The twelfth and thirteenth centuries saw the use of rhymed verse spread through such diverse disciplines as medicine, law, meteorology and literary history. Leonin, the earliest known composer of polyphony, put the first eight books of the Old Testament into dactylic hexameter; monks memorized rhyming library catalogues. ${ }^{32}$ But though it aided memory, end-rhyme did not aid comprehension or interpretation: Latin and Uncial script generally lacked word-breaks and punctuation, and novices working in a new language needed unambiguous prosodic cues in order to group words into sense-units with the right intonation and pacing. Gregorian chant, as the brilliant analyses of Calvin Bower ${ }^{33}$ and Leo Treitler demonstrate, served to "project the sound structure and meaning [of the liturgical text] with maximum distinctness, while at the same time being faithful to principles of melodic syntax and grammar that assure coherence of idiom and genre."34

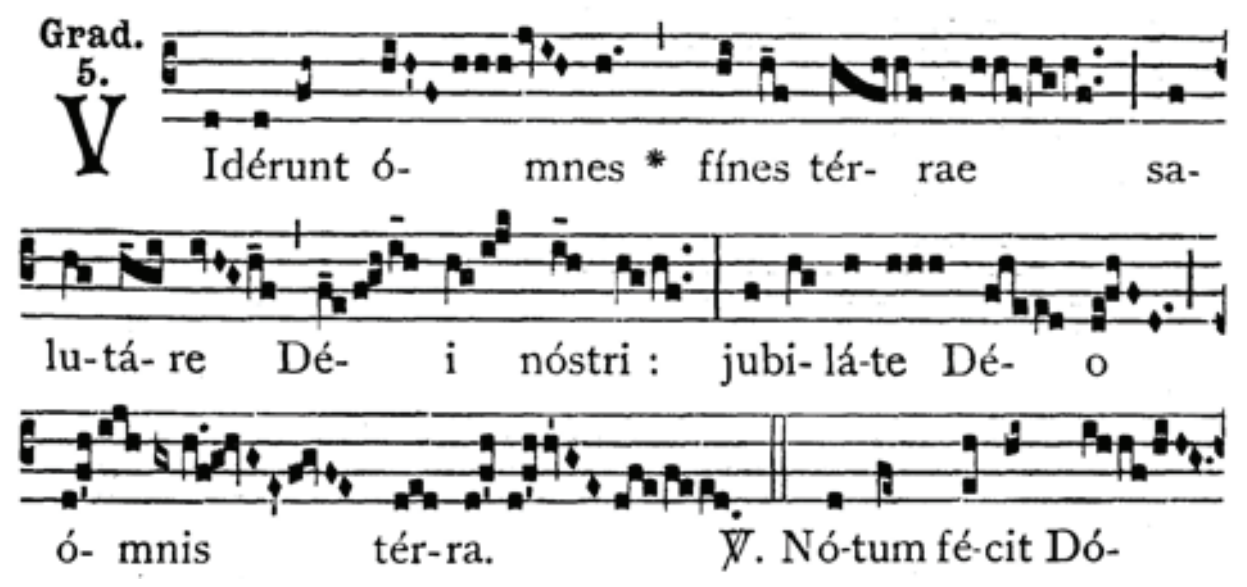

Example 1: Viderunt Omnes, Liber Usualis No. 406, Gr. 33.

30 Seán Connolly, "Vita Prima Sanctae Brigitae Background and Historical Value", The Journal of the Royal Society of Antiquaries of Ireland 119 (1989): 40, http://www.jstor.org.proxy.lib.sfu.ca/stable/25508969. Accessed May 15, 2013.

31 George H. Brown, "The Psalms as the Foundation of Anglo-Saxon Learning", in The Place of the Psalms in the Intellectual Culture of the Middle Ages, ed. Nancy van Deusen (Albany, NY: The State University of New York Press, 1999), 5.

32 Anna Maria Busse Berger, "Mnemotechnics and Notre Dame Polyphony", The Journal of Musicology, vol. 14, no. 3 (Summer 1996): 276 .

33 Calvin M. Bower, "The Grammatical Model of Musical Understanding in the Middle Ages", in Hermeneutics and Medieval Culture, eds. Patrick J. Gallacher and Helen Damico (Albany, NY: State University of New York Press, 1989), 133-146.

34 Leo Treitler, "The 'Unwritten' and 'Written Transmission' of Medieval Chant and The Start-Up of Musical Notation”, The Journal of Musicology, vol. 10, no. 2 (Spring 1992): 139, http://www.jstor.org/stable/763611. Accessed May 24, 2013. 
But to the principles of which melodic syntax is Gregorian chant faithful? Most cultic chant uses a narrow tonal range, subtle microtonal elaborations, and irregular rhythms. Gregorian chant, however, is distinctive for its full octave range and its rhythmic and diatonic simplicity. The structure and syntax of the Gregorian chant Viderunt Omnes reveal harmonious proportions. The finalis and opening tone of the chant, $\mathrm{F}$, is also the highest and lowest tone, and the last tone of the melismas on Dei and Deo respectively. This pure and unified tonal framework corresponds to the cubic dimensions of the Holy of Holies in the temple of ancient Israel (I Kings 6:20).

As is appropriate for an announcement of salvation, the chant begins with a heraldic trumpet call on viderunt, elaborates the fifth on the first melismatic omnes, and moves through the overtones to the penultimate seventh before dropping down to end the word. Fines repeats the first four notes of the omnes, and terrae reverberates four times (to the four corners of the earth, Isaiah 7:2), in echoing minor thirds. The minor third (3:5) is the ratio of the ark of the covenant (Exodus 25:10), the meeting-place of the human and divine. Musical "end-rhyme" is evident in the repeating four-note falling motif ending terrae, salutarae and nostri. Deo ends with a "comma"-i.e. a descending F triad which anticipates the recapitulation. The second omnes recapitulates the opening viderunt omnes, complete with the trumpet motif extending to the penultimate seventh and the descending four-note sequence. The final terra features a double trumpet call and concludes with a reference to the minor-third echoes of the earlier terrae. The harmonious architectonics of the temple of ancient Israel which were carried through into Gothic architecture can thus be traced in the syntax of this Gregorian melody, which in turn elucidates the syntax of the sacred text.

The role of tone for comprehensible and meaningful speech was well-recognized in ancient Greek and medieval rhetoric. Guido d'Arezzo wrote:

Also, the beginnings of chants can be made on all those pitches which agree with the final pitch [...] And who does not understand that from pitches are made, as it were, syllables and words and phrases or lines of verse? 35

In Guido's time, music was undergoing a significant transformation. Diastemic notation, which correlates the height of musical pitch with a high or low location on a line or set of staff lines, made it possible for the first time to create a harmonized interplay of simultaneous independent voices by means of contrapuntal techniques that still pervade musical practice. Nancy van Deusen argues that early polyphony was a sonic model of ultimate reconciliation:

[It] uniquely exemplified an absolutely pivotal concept. Motions [...] which appeared to oppose [...] could be made to be reconciled [. . .] The point of reconciliation, of simultaneous consonance, was the point of rest, the quies media. Musical counterpoint [...] made this plain to the ear and, in music notation, to the eye as well. Thus this difficult idea of contrary motion [...] influenced the composition of music for the next 600 years. No other concept in the history of western music has had such power."36

35 Dolores Pesce, Guido D'Arezzo's Regule rithmice, Prologus in antiphonarium, and Epistola ad michahelem (Ottawa: Institute of Mediaeval Music, 1999), 528-9.

36 Nancy van Deusen, Theology and Music at the Early University: The Case of Robert Grosseteste and Anonymous IV (Leiden, New York: E. J. Brill, 1995), 18. 
The early polyphony of the Notre-Dame school is admittedly artificial-sounding. Vowels are prolonged well past the limits of comprehensible speech, and push the limits of vocal stamina. The upper parts are highly rhythmic, with rapid changes of melodic contour - an unusually bouncy way of singing extended vowels. It is surely unlikely that such four-part organum arose as a mere elaboration or evolutionary development of plainchant. Here follows an alternative hypothesis for the emergence of this musical phenomenon utilizing the concept of kairos.

Diastemic notation makes possible not only precise tonal intervals, but also mensural or measured music: if one could not predict the tone a fellow-chorister was about to sing, there would be no use in coordinating melodies by counting in beats. Diastemic notation certainly gave rise to new musical forms, but the historicist assumption that mensural music superceded previous forms is an oversimplification. Sacred chant was held to be exempt from measure: Johannes de Garlandia's late $13^{\text {th }}$ century treatise, Concerning Measured Music, opened, "Having spoken about plainchant, which is unmeasured," ${ }^{37}$ which was then quoted at least twice in Anonymous IV's De Mensuris et Discantu.$^{38}$ However, the new mensuration technique made possible the simultaneous combination of a measured discantus and a virtually unmeasured cantus firmus, that is, a sonic depiction of chronos and kairos.

The terms cantus planus and cantus firmus originate at this time, significantly linking music to cosmic structure. Augustine recognized two firmaments: the firmament of the starry heavens, and the firmament of God's revealed word:

It is said, For heaven shall be folded up like a scroll; and now is it stretched over us like a skin [...] Thou hast like a skin stretched out the firmament of Thy book, that is, Thy harmonizing words [...], announcing in time Thee Who madest times. 39

In the cantus firmus of Perotin's four-part setting of Viderunt Omnes the Psalm - the word of God - is indeed stretched like a skin under the lively perichoresis of the three upper voices; the word viderunt alone lasts around a minute and a half.

The elaborately prepared cadences of Notre Dame polyphony enhanced and extended the impact of the penultimate in an entirely new way. Anonymous IV famously wrote, "There are some who multiply many kinds of discords before one perfect concord, like before an octave, and rejoice and laugh greatly on that account, and it seems to be a great and wonderful thing to them, that this can be done." ${ }^{40}$ In Perotin's protracted cadences, the pleroma - the summation of all things - could hardly be more vividly presented.

37 John of Garland, Concerning Measured Music (De Mensurabili Musica), trans. Stanley H. Birnbaum (Colorado Springs: Colorado College Music Press, 1978), 1.

38 Yudkin, Jeremy, trans., The Music Treatise of Anonymous IV: A New Translation, Musicological Studies and Documents 41 (Neuhausen-Stuttgart: Hänssler-Verlag, American Institute of Musicology, 1985), 25, 38.

39 Augustine of Hippo, Confessions, Book XIII, Ch. 15, trans. Edward Bouverie Pusey (1909-14), http://www.sacred-texts.com/ chr/augconf/aug13.htm. Accessed May 24, 2013.

40 Yudkin, Anonymous IV, 70-71. 


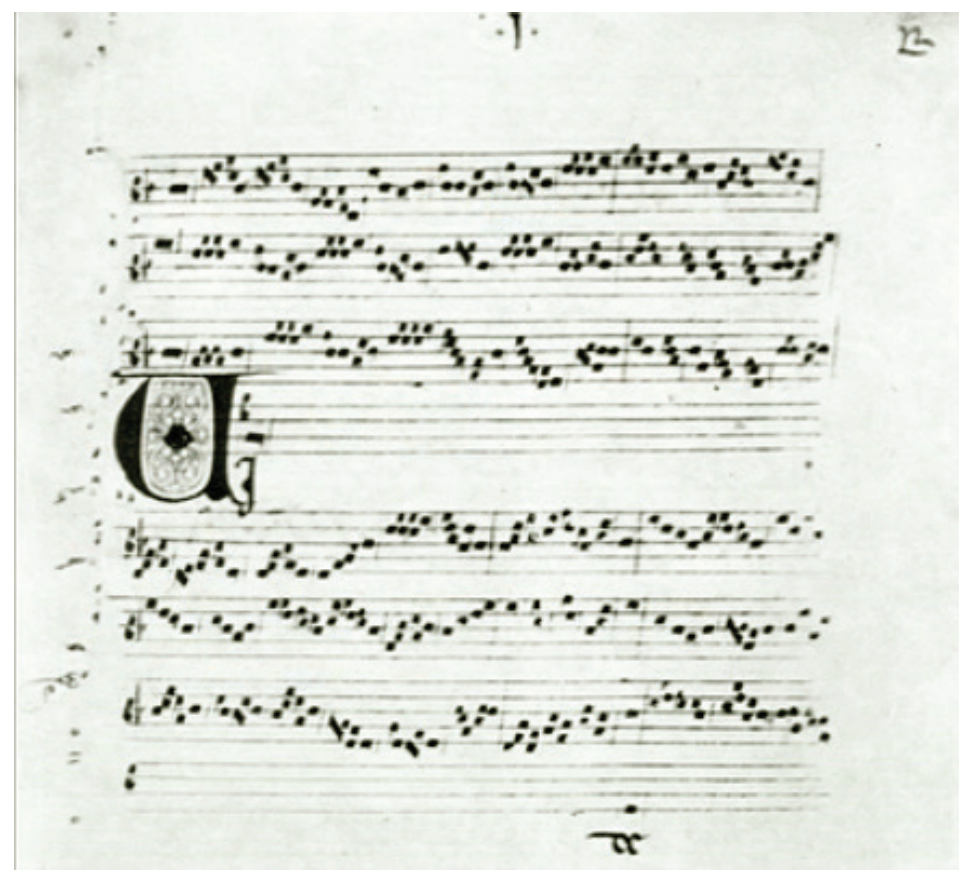

Example 2: Viderunt Omnes, MS Pluteo 29, 1, Bibliotheca Mediceo-Laurenziana, Florence.

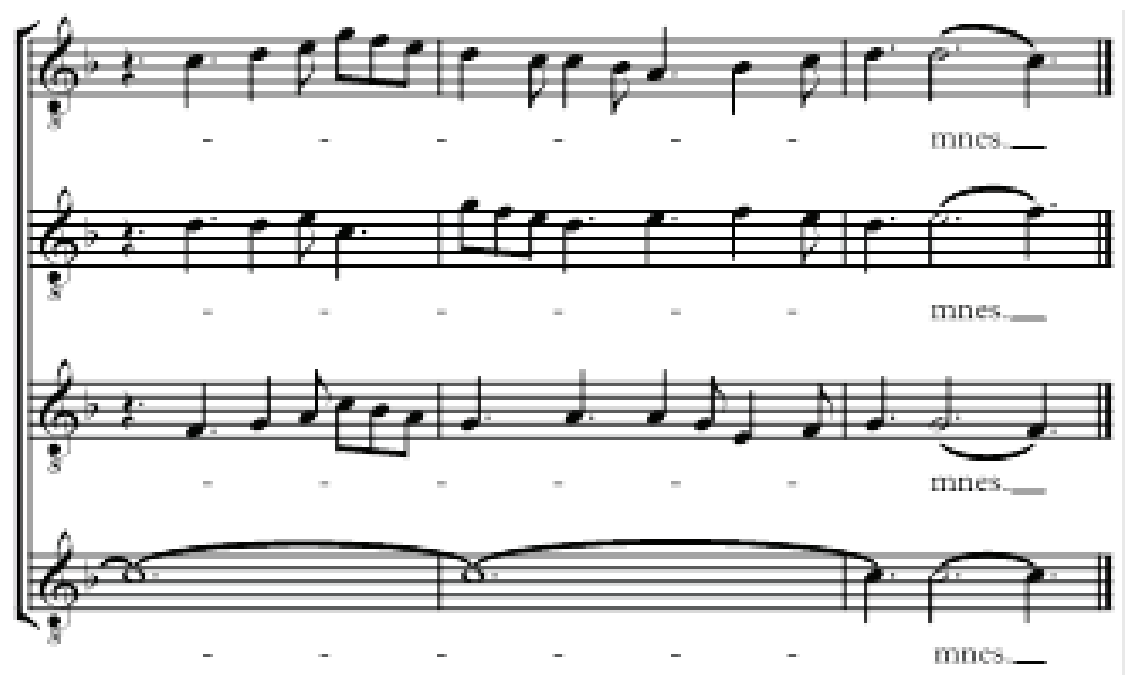

Example 3: Cadence at mm. 87-89 in Perotin's four-part Viderunt Omnes. 
The first Notre-Dame polyphony was written as Aristotle's works were being recovered, and Aristotle's assertion that the cosmos was eternal stimulated much discussion. Concepts related to messianic time such as tota simul, succession, and temporal division were revisited and debated. ${ }^{41}$ Perotin's polyphonic demonstration of simultaneous, intersecting time frames - kairos in tones- may have been a significant contribution to those debates.

While Agamben's thought has shed light on key developments in harmony and time, we have not yet discussed sacrifice. Agamben finds the sacrificial system fully operational in today's biopolitical sphere, our own homines sacri are swelling the desperate populations of refugee camps in unprecedented numbers.

Secularization is a form of repression. It leaves intact the forces it deals with by simply moving them from one place to another. Thus the political secularization of theological concepts (the transcendence of God as a paradigm of sovereign power) does nothing but displace the heavenly monarchy onto an earthly monarchy, leaving its power intact. ${ }^{42}$

Agamben's book Profanations, referencing Walter Benjamin's "Capitalism as Religion," describes this new earthly monarchy as a rampant capitalism developing parasitically from Christianity; however, "capitalism as religion does not aim at the transformation of the world but at its destruction." ${ }^{43}$ This destruction results from the cult of consumption, which has replaced the sacrificial act:

What cannot be used is, as such, given over to consumption or to spectacular exhibition [...] If to profane means to return to common use that which has been removed to the sphere of the sacred, the capitalist religion in its extreme phase aims at creating something absolutely unprofanable. ${ }^{44}$

For Agamben, spectacular exhibition is exemplified by the museum:

The Museum occupies exactly the space and function once reserved for the Temple as the place of sacrifice. To the faithful in the Temple - the pilgrims who would travel across the earth from [...] sanctuary to sanctuary - correspond today the tourists who restlessly travel in a world that has been abstracted into a Museum. Tourism is the primary industry in the world, involving more than six hundred and fifty million people each year [...] carry out on their own flesh what is perhaps the most desperate experience that one can have: the irrevocable loss of all use, the absolute impossibility of profaning. ${ }^{45}$

41 Cf. Richard C. Dales, "Time and Eternity in the Thirteenth Century," Journal of the History of Ideas vol. 49, no. 1 (Jan.-Mar. 1988), 27-45.

42 Agamben, Profanations, 77.

43 Ibid., 80.

44 Ibid., 82.

45 Agamben, Profanations, 84-5. Wikipedia's Tourism entry (http://en.wikipedia.org/wiki/Tourism, accessed May 25, 2013) cites the 2012 "World Tourism Statistics and Rankings" showing more than one billion people involved in tourism. 
"Exhibition-value" has taken the place of use-value and exchange-value. ${ }^{46}$

Agamben's demonization of capitalism may be overdrawn, but it suggests why the early twentieth-century overthrow of the old gods failed its promise. It neglected to vanquish Mammon, who was in the wings scoffing at the rhetoric of artistic liberation. Today Stravinsky and Schoenberg are uneasily sequestered in concert hall-museums amongst the many composers in powdered wigs whom they had hoped to supplant, while commercial music asserts its omnipresence and omnipotence with fully technologized pomp. Agamben challenges us to make profane music, resisting both the museum/concert hall and commodification: a daunting challenge that will involve carefully discerning what we have faith in-that is, to whom or to what we make sacrifice; what times we hope for; and whom we harmoniously love, with due regard to our penultimate situation.

\section{Bibliography}

Agamben, Giorgio. Homo Sacer: Sovereign Power and Bare Life. Translated by Daniel Heller-Roazen. Stanford, California: Stanford University Press, 1998.

Agamben, Giorgio. Profanations. Translated by Jeff Fort. Cambridge, Mass: Zone Books, distributed by MIT Press, 2007.

Agamben, Giorgio. The Time That Remains: A Commentary on the Letter to the Romans. Translated by Patricia Dailey. Stanford, CA: Stanford University Press, 2005.

Augustine of Hippo. Confessions. Translated by Rex Warner. New York: New American Library, 1963.

Augustine of Hippo. Confessions. Book XIII, Ch. 15. Translated by Edward Bouverie Pusey, 1909-14. Accessed May 24, 2013. http://www.sacred-texts.com/chr/augconf/aug13.htm.

Athanasius of Alexandria. On the Incarnation: The Treatise De Incarnatione Verbi Dei. Crestwood, NY: St. Vladimir's Press, 1993.

Barker, Andrew. Greek Musical Writings I: The Musician and his Art. Cambridge: Cambridge University Press, 1984.

Barker, Andrew. Greek Musical Writings II: Harmonic and Acoustic Theory. Cambridge: Cambridge University Press, 1989.

Beare, W. "The Origin of Rhythmic Latin Verse." Hermathena, No. 87 (May 1956): 3-20. Accessed May 26, 2013. http://www.jstor.org/stable/23039054.

Benjamin, Walter. "Critique of Violence." In Reflections: Essays, Aphorisms, Autobiographical Writings. Edited by and with an Introduction by Peter Demetz; translated by Edmund Jephcott. New York: Schocken Books, 1986, c1978.

Bower, Calvin M. "The Grammatical Model of Musical Understanding in the Middle Ages." In Hermeneutics and Medieval Culture. Edited by Patrick J. Gallacher and Helen Damico, 133-146. Albany, NY: State University of New York Press, 1989.

Brown, George H. "The Psalms as the Foundation of Anglo-Saxon Learning." In The Place of the Psalms in the Intellectual Culture of the Middle Ages. Edited by Nancy van Deusen, 1-24. Albany, NY: The State University of New York Press, 1999. 
Busse Berger, Anna Maria. "Mnemotechnics and Notre Dame Polyphony." The Journal of Musicology, Vol. 14, No. 3 (Summer 1996): 263-298.

Connolly, Seán. "Vita Prima Sanctae Brigitae Background and Historical Value."

The Journal of the Royal Society of Antiquaries of Ireland 119, (1989):5-49. Accessed

May 15, 2013. http://www.jstor.org.proxy.lib.sfu.ca/stable/25508969.

Crombie, A. C. Science, Art and Nature in Medieval and Modern Thought. London: Hambleton Press, 1996.

Dales, Richard C. "Time and Eternity in the Thirteenth Century." Journal of the History of Ideas Vol. 49 No. 1 (Jan.-Mar. 1988): 27-45. Accessed October 18, 2013. http://www. jstor.org/stable/2709702.

DeWoskin, Kenneth J. A Song for One or Two: Music and the Concept of Art in Early China. Michigan Monographs in Chinese Studies Volume 42. Ann Arbor, MI: Centre for Chinese Studies, The University of Michigan, 1982.

Franklin, John Curtis. "Diatonic Music in Greece: A Reassessment of Its Antiquity.” Memnosyne, Fourth Series, Vol. 55, Fasc. 6 (2002): 669-702. Accessed May 19, 2013. http:// www.jstor.org/stable/4433380.

Godwin, Joscelyn, ed. The Harmony of the Spheres: A Sourcebook of the Pythagorean Tradition in Music. Rochester, Vermont: Inner Traditions International, 1993.

Hartleben, Otto Erich, after Albert Giraud. Pierrot Lunaire. Translated by Andrew Porter, 1984. http://www.da-capo.org/html/PierrotEnglish.html.

Hindemith, Paul. A Concentrated Course in Traditional Harmony Book 1. New York: Schott, 1943.

John of Garland. Concerning Measured Music (De Mensurabili Musica). Translated by Stanley H. Birnbaum. Colorado Springs: Colorado College Music Press, 1978.

Johnston, Richard. W. and David Mulroy. "The Hymn to Hermes and the Athenian Altar of the Twelve Gods." The Classical World, 103, No. 1 (Fall 2009): 3-16. Accessed May 19, 2013. http://www.jstor.org/stable/40599900.

Kruchenyky, Aleksei. Victory Over the Sun. Translated by Larissa Shmailo, 2012. http:// intranslation.brooklynrail.org/russian/victory-over-the-sun.

Newton, Isaac. Scholium to the Definitions in Philosophiae Naturalis Principia Mathematica, Book 1 (1689). Translated by Andrew Motte (1729), rev. Florian Cajori. Berkeley: University of California Press, 1934.

Pesce, Dolores. Guido D'Arezzo's Regule rithmice, Prologus in antiphonarium, and Epistola ad michahelem: a critical text and translation with an introduction, annotations, indices, and new manuscript inventories. Ottawa: Institute of Mediaeval Music, 1999. Smith, Robertson. The Religion of the Semites. Edinburgh: Adam \& C. Black, 1894.

Spitzer, Leo. Classical and Christian Ideas of World Harmony: Prolegomena to an Interpretation of the Word "Stimmung." Baltimore: The Johns Hopkins Press, 1963. Steiner, Franz. Taboo. Translated by Laura Bohannan. London: Cohen \& West, 1956. Stupples, Peter. "Malevich and the Liberation of Art." New Zealand Slavonic Journal (2001): 11-36. Accessed October 19, 2013. http://www.jstor.org/stable/40922063.

Treitler, Leo. “The 'Unwritten' and 'Written Transmission' of Medieval Chant and The Start-Up of Musical Notation.” The Journal of Musicology, Vol. 10, No. 2 (Spring 1992): 131-191. Accessed May 24, 2013. http://www.jstor.org/stable/763611. 
Treitler, Leo. With Voice and Pen: Coming to Know Medieval Song and How It Was Made. Oxford: Oxford University Press, 2003.

van Deusen, Nancy Elizabeth. Theology and Music at the Early University: The Case of Robert Grosseteste and Anonymous IV. Leiden, New York: E. J. Brill, 1995.

Yudkin, Jeremy, translator. The Music Treatise of Anonymous IV: A New Translation. Musicological Studies and Documents 41. Neuhausen-Stuttgart: Hänssler-Verlag, American Institute of Musicology, 1985.

\section{POVZETEK}

V harmoniji zgodnjega 20. stoletja sta bila žrtvovanje in čas orisana kot prvinska predhodnika miru, blagostanja in napredka. Ta koreniti pomenski zasuk je našel svoj glasbeni izraz, ko je Schönberg opravil s harmonijo, Stravinski uporabil pretanjeni orkestrski zvok za slikanje okrutnega žrtvovanja, ustvarjalci ruske futuristične opere pa preizkušali možnost življenja brez preteklosti. Nove znanstvene discipline, antropologija, psihoanaliza in fizika so - kot se je zdelo - podprle prizadevanja za umetniško - in človeško - svobodo s tem, da so harmonijo, sakralno in čas prikazale kot sredstvo prisile.

Kasneje je italijanski filozof Giorgio Agamben raziskoval pomen sakralnega. V antičnem Rimu, je sacre pomenilo odmik stvari ali oseb izpod vladavine in zaščite človeškega prava $\mathrm{v}$ domeno bogov. Nasprotno so zgodnji grški, hebrejski in kitajski pisci, kot npr. homerska himna Hermesu, predvidevali, da sta glasba in žrtvovanje pot v svet bogov, harmonija pa povezujoča skladnost ubranega stvarstva.

Agamben je raziskoval tudi spremenjeni pogled na čas, kakršnega najdemo v obdobju zgodnjega krščanstva, ki je slavilo preboj meje med umrljivostjo in neumrljivostjo. Pavlovo Pismo Rimljanom se spoprijema z daljnosežnimi posledicami te spremembe. Pavel uporablja grško besedo kairos, "sedanjost" za čas med Kristusovim vstajenjem in parousia, koncem časov. Kairos označuje polnost časa, v katerem se povezujeta preteklost in sedanjost, obe pa sta predzadnji. Pavel je pri poskusu, da bi pojasnil posledice kairos, ustvaril novo pesniško tehniko: prve primere končne rime, tako Agamben, najdemo prav v Pavlovih pismih.

V srednjem veku je bil kairos še naprej ključen za oblikovanje krščanske liturgične in monastične prakse. Končna rima je bila široko uporabljana za olajšanje pomnenja, gregorijanski koral je pospeševal učenje ključnih besedil, npr. psalmov. Gregorijanski spevi, kot je npr. Viderunt Omnes, so prinašali pomembne prozodične zglede, ki so pojasnjevali skladnjo in bogatili besedilo z bibličnimi aluzijami, vključno s harmonskimi proporci nekdanjega jeruzalemskega templja.

Tudi pojav večglasja v 13. stoletju lahko razumemo kot razvijanje prikazovanja kairos. Perotinova štiriglasna obdelava Viderunt Omnes vsebuje tako ritmično določeno, kot ritmično svobodno glasbo. Tehnika cantusa firmusa oživlja starodavno idejo nebesnega svoda, širne ravnine, ki ločuje vidni, času podložni svet od nevidnega, sakralnega. Raztegnjene kadence, ki sledijo ostrim disonancam, so simbol sprave. Povod za nastanek zapletenih in precej nenaravno zvenečih organumov bi bile lahko razprave o pravkar odkritih Aristotelovih delih pri Notre-Dame - še posebej o tem, da je bil za Aristotla kozmos večen. Ogranum je pokazal, da lahko različna časa - kronos in kairos - sobivata in se dotikata.

Če je žrtvovanje darovanje oseb ali predmetov za uporabo v svetišču ali območju sakralnega, je profanacija vrnitev iz svetišča, oskrunjenje. Agamben razume muzeje, katerih inventar ljudem ni več na voljo za uporabo, kot sodobno ustreznico svetišč. Kapitalizem obsoja, da je onemogočil profanacijo: umetnostna dela, kot vse drugo, vključno s človeškimi telesi, postanejo objekti; bodisi za bleščečo razstavo, ali za golo potrošnjo. Zato so tudi zgoraj omenjene potencialno revolucionarne skladbe skladateljev zgodnjega 20. stoletja kmalu končale v muzejih koncertnih dvoran, medtem ko se ogromni dobički kujejo z ustvarjanjem porabne glasbe. Agambenovo delo izziva skladatelje k ustvarjanju glasbe, ki jo je mogoče profanirati.

Prevod naslova, izvlečka in povzetka Aleš Nagode 